\title{
Implementasi Kebijakan Pembinaan Bahasa Daerah di Kabupaten Jember, Situbondo dan Banyuwangi
}

\author{
Budi Suyanto \\ Fakultas Ilmu Budaya Universitas Jember \\ busyuanta@gmail.com
}

Diterima 11 Mei 2015/Disetujui 20 Juni 2015

\begin{abstract}
This study discusses about the relation between students' bilingualism (particularly second language learners) acquired through studying at school and student's capability in inter-ethnic social interaction. It is assumed that local language teaching at school provides students capability of bilingualism. Students' bilingualism plays important role in their multicultural perspective endorsing them to have tolerance and solidarity to different ethics and culture, all of which are the factors to build harmony in plural society. Observed subjects are secondary school students with plural cultural backgroundsin Jember, Situbondo, and Banyuwangi. As a matter of fact, people in those three regencies have plural cultural background, however, the teaching of local language is different. This research is conducted with analytic-quantitative paradigm. Data analysis is conducted in two ways: (a) qualifying andgeneralizing dataand (b) qualifying and relating data with their social context. The result shows that (1) learning local language at 6 secondary schools in the three regencies has impact ondifferent achievements concerning students' bilingualism; (2) there is a correlation between students' bilingualismand their capability of having interaction with different ethnic; (3) there is a correlation between students' language performance and their solidarity, tolerance and integrity with people of different ethnics. (4) the consequence of teaching only majorities' local language is that students' of major ethnic merely have competence of their own local language, and thus have less capability of bilingualism concerning local language of different ethnic. Students' linguistic repetoir are not improved. On the other hand, students from minor ethnic do not get competence of their own local language but get other ethnic's local language instead. Students of minor ethnic have advantage in that they are able to take part in their social role using their competence of major ethnic's local language. However, it also has negative impact in that they have limited competence in their own local language and culture, and gradually lose their own identity as they become dominated by major ethnic.
\end{abstract}

Keywords: language teaching, multiculturalism, bilingualism, intercultural communication

\section{Pendahuluan}

Penelitian ini dilatarbelakangi oleh adanya ketidaksesuaian antara tuntutan kehidupan multikulturalisme dengan kebijakan Pemerintah Daerah dalam upaya pengembangan dan pembinaan bahasa daerah di Kabupaten Jember, Kabupaten Situbondo, dan Kabupaten Banyuwangi. Pengajaran bahasa daerah di sekolah-sekolah merupakan upaya strategis yang ditempuh oleh pemerintah daerah dalam melakukan pembinaan penggunaan bahasa daerah terhadap masyarakat. Kebijakan pengajaran bahasa daerah di tiga kabupaten tersebut tampaknya dilandasi oleh pandangan bahwa bahwa Jember identik dengan Jawa, Bondowoso identik dengan Madura, dan Banyuwangi identik dengan Using. Kebijakan yang dilandasi oleh pandangan seperti itu tidak sesuai dengan multikulturalime karena sekarang ini kondisi masyarakat di tiga kabupaten itu bersifat multietnik, multikultur, dan multilingual. 


\section{Implementasi Kebijakan Pembinaan Bahasa Daerah di Kabupaten Jember, Situbondo dan Banyuwangi (Budi Suyanto)}

Pengajaran bahasa daerah sebagai implementasi pembinaan dan pengembangan bahasa daerah belum dijiwai oleh nilai-nilai multikulturalisme Kurikulum pengajaran bahasa daerah (komponen muatan lokal) yang diterapkan lebih menitikberatkan kepada bahasa daerah dan budaya etnik mayoritas dan mengabaikan etnik minoritas. Kebijakan ini terkesan sebagai konstruksi Jawanisasi, Maduranisasi, Usingisasi, dan marjinalisasi terhadap etniketnik lain. Kebijakan ini tentu kurang menguntungkan bagi etnik minoritas karena bahasa dan budayanya tidak diberi peluang untuk berkembang menjadi bahasa yang memungkinkan budaya atau cara berfikir etnik itu berkembang. Kebijakan seperti ini dapat menimbulkan kecemburuan sosial dan benih konflik.

Dewasa ini banyak sekolah yang hanya mengajarkan atau memberi satu kompetensi bahasa daerah, meskipun lingkungan sekolah itu bersifat multietnik dan multilingual. Sekolah-sekolah pada umumnya lebih mengutamakan pengajaran bahasa daerah etnik mayoritas dan mengabaikan bahasa etnik minoritas. Kebijakan seperti ini kurang relevan dengan nilai-nilai multikulturalisme karena dapat memarjinalkan bahasa dan budaya etnik minoritas itu.

Muatan lokal dalam KTSP mestinya disusun dengan satuan-satuan pelajaran yang memungkinkan peserta didik kelak memiliki kemampuan dan kesanggupan (soft skill) berkomunikasi dengan etnik lain, dapat diterima dan dapat menjalin hubungan yang kohesif dengan orang-orang di sekitarnya yang memiliki perbedaan dengan dirinya, baik perbedaan etnik, bahasa, budaya, agama, dsb. Pengajaran bahasa etnik (minoritas) memungkinkan anak didik yang berbahasa ibu etnik minoritas tersebut dapat mengembangkan kemampuan intelektualnya, mampu mengembangkan budayanya, dan mampu mempertahankan identitas keetnikannya.

Kajian dalam artikel ini memfokuskan pada pembelajaran bahasa daerah sebagai implementasi kebijakan pembinaan bahasa daerah dengan kondisi siswa dan lingkungan sosialnya, serta output pada kemampuan siswa dalam menjalin interaksi sosial antaretnik dan kemampuan memelihara kohesivitas sosial.

\section{Metode}

Data penelitian berupa informasi. Data dikumpulkan dengan dua cara, yaitu survei dan wawancara. Survei dilakukan untuk menjaring informasi melalui kuesioner. Kuesioner dibagikan kepada para siswa dan para guru sebagai responden. Metode wawancara dilakukan untuk menggali informasi latar belakang sosial budaya di daerah itu. Data yang berhasil dikumpulkan diklasifikasi, ditabulasi, dan dikuantifikasi berdasarkan tujuan-tujuan penelitian. Tujuan penelitian, yakni memecahkan masalah dan menguji hipotesis merupakan suatu kesatuan yang membimbing ke arah mana analisis data harus dilakukan (Mahsun, 2005:229).

Analisis data dilakukan dengan menggunakan paradigma analitik-kuantitatif dan deskriptif analitik. Dari paradigma ini penelitian dijalankan dengan menemukan karakteristik segala sesuatu. Kebenaran dibuktikan berdasarkan frekuensi tinggi atau variansi besar. Bukti berupa data kuantifikasi. Frekuensi tinggi atau variansi besar dari jenis yang satu (variabel) apabila sejalan frekuensi atau variansi dengan jenis/variabel yang lain dikatakan mempunyai relevansi atau korespondensi positif. Bila berlawanan arah disebut korelasi negatif. Data dianalisis dengan cara kuantifikasi angka dan verbal.

Analisis data dengan metode deskriptif analitik, yakni penggunaan konsep-konsep, proposisi-proposisi, dan generalisasi empiris dari suatu teori ilmiah sebagai panduan dasar dalam menganalisis data kualitatif. Peneliti memahami secara refleksif terhadap nilai-nilai 
yang dianut oleh masyarakat dan pengetahuan mereka yang berpengaruh pada cara memahami atau merespon apa yang dihadapi.

\section{Pembahasan}

3.1 Pemakaian Bahasa oleh Siswa dalam Ranah Keluarga, Sosial, dan Sekolah

Untuk mengetahui gambaran kebilingualan siswa perlu diketahui gambaran pemakaian bahasa oleh siswa yang (dijadikan responden) dalam ranah keluarga, sosial, dan pendidikan. Pemakaian bahasa dalam ranah keluarga tergambar pada Tabel (1). Setiap daerah menunjukkan pemakaian bahasa yang berbeda-beda dengan besaran kuantifikasi yang tidak sama. Di daerah Mangaran (112 orang atau 95\% dari 118 responden) dan Kapongan (82 orang atau 81\% dari 118 responden) siswa menggunakan bahasa Madura ketika berinteraksi dengan orang tuanya. Sisanya menuturkan bahasa Indonesia (4\%) dan bahasa Jawa (1\%). Di Muncar siswa yang menuturkan bahasa Jawa ketika berbicara dengan orang tuanya sebanyak 105 orang atau $85 \%$ dari 124 responden, bahasa Madura sebanyak 15 orang atau 12\%, dan bahasa Indonesia sebanyak 5 orang atau 4\%. Di Muncar siswa yang menuturkan bahasa Jawa ketika berbicara dengan orang tuanya sebanyak 59 orang atau 51\% dari 115 responden, bahasa Using sebanyak 30 orang atau $26 \%$, dan bahasa Indonesia sebanyak 14 orang atau $12 \%$. Di Sukorambi siswa yang menuturkan bahasa Jawa ketika berbicara dengan orang tuanya sebanyak 85 orang atau $70 \%$ dari 122 responden, bahasa Madura sebanyak 20 orang atau $16 \%$, dan bahasa Indonesia sebanyak 17 orang atau 14\%. Di Patrang siswa yang menuturkan bahasa Jawa ketika berbicara dengan orang tuanya sebanyak 61 orang atau $48 \%$ dari 126 responden, bahasa Madura sebanyak 10 orang atau $8 \%$, dan bahasa Indonesia sebanyak 33 orang atau $26 \%$.

Tabel 1. Pemakaian Bahasa oleh Siswa dalam Ranah Keluarga

\begin{tabular}{|c|c|c|c|c|c|c|c|c|c|c|c|c|c|}
\hline \multirow[b]{2}{*}{ Kecamatan } & \multicolumn{12}{|c|}{ Pemakaian Bahasa antara Anak dengan Orang Tua dalam Keluarga } & \multirow[b]{2}{*}{ Res } \\
\hline & IN & JW & $\begin{array}{c}\mathrm{M} \\
\mathrm{A}\end{array}$ & US & $\mathrm{JM}$ & JU & JI & $\mathrm{U} 1$ & MI & JMI & $\mathrm{BL}$ & TJ & \\
\hline Mangaran & 5 & 1 & 112 & - & - & - & - & - & - & - & - & - & 118 \\
\hline Kapongan & 16 & 2 & 82 & - & - & - & - & - & 1 & - & - & - & 101 \\
\hline Muncar & 5 & 105 & 15 & - & - & - & - & - & - & - & 1 & - & 124 \\
\hline Rogojampi & 14 & 59 & - & 30 & - & 5 & 2 & - & - & - & 1 & 4 & 115 \\
\hline Sukorambi & 17 & 85 & 20 & - & - & - & - & - & - & - & - & - & 122 \\
\hline Patrang & 33 & 61 & 10 & - & 4 & - & $\begin{array}{l}1 \\
4\end{array}$ & 1 & 1 & 2 & - & - & 126 \\
\hline & 90 & 313 & 239 & 30 & 4 & & $\begin{array}{l}1 \\
6 \\
\end{array}$ & 1 & 2 & 2 & 2 & 4 & 706 \\
\hline
\end{tabular}

Keterangan:

IND: bahasa Indonesia; JW: bahasa Jawa; MA: bahasa Madura; US: bahasa Using; JM: bahasa Jawa dan Madura; JU: bahasa Jawa dan bahasa Using; JI: bahasa Jawa dan bahasa Indonesia; MU: bahasa Madura dan bahasa Using; MI: bahasa Madura dan bahasa Indonesia; JMI: bahasa Jawa, Madura, dan Indonesia; BL: bahasa Bali; dan TJ: Tidak Jawab; Res: responden.

Pemakaian bahasa para siswa dalam ranah sosial juga menunjukkan dominasi yang berbeda. Di daerah Mangaran dan Kapongan pemakain bahasa dalam ranah sosial didominasi oleh pemakaian bahasa Madura; di Muncar didominasi oleh pemakaian bahasa Jawa; di Rogojampi pemakaian didominasi oleh dua bahasa, yaitu bahasa Jawa dan bahasa Using. Di Sukorambi dan Patrang pemakaian bahasa didominasi oleh bahasa Jawa (lihat Tabel 2 


\section{Implementasi Kebijakan Pembinaan Bahasa Daerah di Kabupaten Jember, Situbondo dan Banyuwangi (Budi Suyanto)}

Tabel 2. Pemakaian Bahasa oleh Siswa dalam Ranah Sosial

\begin{tabular}{|c|c|c|c|c|c|c|c|c|c|c|c|c|c|}
\hline \multirow{2}{*}{ Kecamatan } & \multicolumn{12}{|c|}{ Pemakaian bahasa antara anak dengan anak lain di kampung } & \multirow{2}{*}{ Res } \\
\hline & IN & JW & MA & US & $\mathrm{JM}$ & $\mathrm{JU}$ & $\mathrm{JI}$ & U1 & MI & JMI & $\mathrm{BL}$ & TJ & \\
\hline Mangaran & 7 & & 110 & 1 & - & - & - & - & - & - & - & - & 118 \\
\hline Kapongan & 11 & 2 & 85 & 1 & - & - & - & - & 1 & - & - & - & 101 \\
\hline Muncar & 3 & 95 & 15 & - & 2 & - & 2 & & 2 & 5 & - & - & 124 \\
\hline Rogojampi & 4 & 48 & - & 44 & - & 10 & 4 & 3 & - & - & 1 & 1 & 115 \\
\hline Sukorambi & 9 & 89 & 21 & - & - & - & 1 & - & - & - & - & 2 & 122 \\
\hline Patrang & 12 & 57 & 12 & - & - & - & 28 & - & 2 & 15 & - & - & 126 \\
\hline & 46 & 291 & 243 & 46 & 2 & 10 & 35 & 3 & 5 & 20 & 1 & 3 & 706 \\
\hline
\end{tabular}

Keterangan:

IN: bahasa Indonesia; JW: bahasa Jawa; MA: bahasa Madura; US: bahasa Using; JM: bahasa Jawa dan Madura; JU: bahasa Jawa dan bahasa Using; JI: bahasa Jawa dan bahasa Indonesia; MU: bahasa Madura dan bahasa Using;

MI: bahasa Madura dan bahasa Indonesia; JMI: bahasa Jawa, Madura, dan Indonesia; BL: bahasa Bali; dan TJ: Tidak Jawab; Res: responden.

Pemakain bahasa dalam ranah pendidikan mengalami perubahan. Pemakaian bahasa Indonesia mengalami peningkatan jika dibandingkan dengan pemakaian dalam ranah yang lain. Peningkatan pemakaian bahasa Indonesia ini karena faktor lingkungan. Di Kecamatan Kapongan peningkatan itu mendekati perimbangan dengan pemakaian bahasa Madura (lihat Tabel 3).

Adanya perubahan pemakaian bahasa dalam tiga ranah tersebut menunjukkan bahwa siswa telah memiliki kemampuan bilingualisme (bahasa daerah dan bahasa Indonesia) yang cukup baik karena perubahan itu menunjukkan adanya aktivitas alih bahasa.

Tabel 3. Pemakaian Bahasa oleh Siswa dalam Ranah Pendidikan

\begin{tabular}{|c|c|c|c|c|c|c|c|c|c|c|c|c|c|}
\hline \multirow[b]{2}{*}{ Kecamatan } & \multicolumn{12}{|c|}{ Pemakaian bahasa antara anak dengan anak lain di kampung } & \multirow[b]{2}{*}{ Res } \\
\hline & IN & JW & MA & US & JM & JU & JI & U1 & $\begin{array}{c}\text { M } \\
\text { I }\end{array}$ & JUI & $\mathrm{BL}$ & TJ & \\
\hline Mangaran & 27 & - & 91 & - & - & - & - & - & - & - & - & - & 118 \\
\hline Kapongan & 41 & - & 57 & - & - & 2 & - & - & - & - & - & 1 & 101 \\
\hline Muncar & 4 & 76 & 9 & - & 3 & - & 32 & - & - & - & - & - & 124 \\
\hline Rogojampi & 12 & 55 & - & 21 & & 11 & 7 & - & - & 6 & & 3 & 115 \\
\hline Sukorambi & 32 & 83 & 2 & & 1 & - & 1 & - & 1 & - & - & 2 & 122 \\
\hline Patrang & 25 & 44 & - & - & 2 & - & 46 & - & 8 & - & - & 1 & 126 \\
\hline & 141 & 258 & 159 & 21 & 6 & 13 & 86 & & 9 & 6 & & 7 & 706 \\
\hline
\end{tabular}

Keterangan:

IND: bahasa Indonesia; JW: bahasa Jawa; MA: bahasa; US: bahasa Using; JM: bahasa Jawa dan Madura; JU: bahasa Jawa dan bahasa Using; JI: bahasa Jawa dan bahasa Indonesia; MU: bahasa Madura dan bahasa Using; MI: bahasa Madura dan bahasa Indonesia; JMI: bahasa Jawa, Madura, dan Indonesia; BL: bahasa Bali; dan TJ: Tidak Jawab; Resp: responden. 
Pada Tabel 4 bilingualisme siswa jika kemampuan bahasa Indonesia diabaikan (dan hanya kemampuan menggunakan dua atau lebih bahasa daerah yang diperhatikan), maka jumlahnya menjadi kurang signifikan. Di SMP Negeri I Kapongan siswa yang bilingual (yang menguasai bahasa daerah etnik lain) berjumlah 18 orang atau 18\% dari 101 responden. Di SMP Negeri I Mangaran siswa yang bilingual (yang menguasai bahasa daerah etnik lain) berjumlah 10 orang atau 8\% dari 118 responden. Di SMP Negeri I Rogojampi siswa yang bilingual (yang menguasai bahasa daerah etnik lain) berjumlah 83 orang atau $72 \%$ dari 116 responden. Di SMP Negeri I Muncar siswa yang bilingual (yang menguasai bahasa daerah etnik lain) berjumlah 34 orang atau 27\% dari 124 responden.

Tabel 4. Bilingualisme Siswa Berdasarkan Bahasa-bahasa yang Dikuasainya

\begin{tabular}{|c|c|c|c|c|c|c|c|c|c|c|}
\hline \multirow[b]{2}{*}{ Daerah } & \multirow[b]{2}{*}{ Etnik } & \multicolumn{8}{|c|}{ Bahasa daerah } & \multirow{2}{*}{$\begin{array}{c}\text { Jumlah } \\
\text { Responden }\end{array}$} \\
\hline & & $\mathrm{A}$ & B & $\mathrm{C}$ & $\mathrm{D}$ & $\mathrm{E}$ & $\mathrm{F}$ & G & $\mathrm{H}$ & \\
\hline \multirow[t]{4}{*}{ Kapongan } & JW & 7 & - & - & - & - & - & - & & 101 \\
\hline & MA & 8 & - & 1 & - & - & 83 & - & - & \\
\hline & $\mathrm{AR}$ & 1 & - & - & - & - & - & - & - & \\
\hline & $\mathrm{JM}$ & 1 & - & - & . & - & - & - & - & \\
\hline \multirow[t]{3}{*}{ Mangaran } & JW & 1 & - & - & . & - & - & - & - & 118 \\
\hline & MA & 8 & - & - & . & - & 108 & - & - & \\
\hline & $\mathrm{JU}$ & 1 & - & - & - & - & - & - & - & \\
\hline \multirow[t]{7}{*}{ Rogojampi } & JW & - & 41 & - & - & 23 & - & - & 1 & 116 \\
\hline & MA & - & 1 & - & 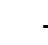 & - & - & - & - & \\
\hline & US & - & 30 & - & . & - & - & 8 & - & \\
\hline & MI & - & - & - & . & - & - & 1 & - & \\
\hline & BU & - & 1 & - & . & - & - & - & - & \\
\hline & JU & - & 9 & - & . & - & - & - & - & \\
\hline & MU & - & - & 1 & 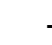 & - & - & - & & \\
\hline \multirow[t]{4}{*}{ Muncar } & JW & 6 & 8 & - & 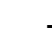 & 89 & - & - & - & 124 \\
\hline & MA & 13 & - & - & . & - & 1 & - & - & \\
\hline & $\mathrm{JM}$ & 4 & - & - & . & - & - & - & - & \\
\hline & JB & 1 & - & 1 & - & - & - & - & 1 & \\
\hline \multirow[t]{6}{*}{ Patrang } & JW & 30 & 1 & - & 1 & 56 & & & 4 & 126 \\
\hline & MA & 3 & - & - & 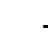 & - & 4 & - & - & \\
\hline & US & - & - & - & . & - & - & - & 1 & \\
\hline & $\mathrm{JM}$ & 14 & - & 2 & 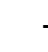 & 4 & 1 & - & - & \\
\hline & JU & 1 & - & - & . & 2 & - & - & - & \\
\hline & JA & 1 & - & - & . & 1 & - & - & - & \\
\hline \multirow[t]{5}{*}{ Sukorambi } & JW & 18 & - & - & . & 82 & - & - & - & 122 \\
\hline & MA & 14 & - & - & 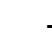 & - & 4 & - & - & \\
\hline & $\mathrm{JM}$ & 3 & - & - & . & - & - & - & - & \\
\hline & $\mathrm{JU}$ & - & 1 & - & . & - & - & - & - & \\
\hline & & 135 & 92 & 5 & 1 & 257 & 202 & 9 & 7 & 707 \\
\hline
\end{tabular}




\section{Implementasi Kebijakan Pembinaan Bahasa Daerah di Kabupaten Jember, Situbondo dan Banyuwangi (Budi Suyanto)}

\begin{tabular}{|c|c|c|c|}
\hline eterangan: & & & \\
\hline A & : bahasa Jawa, Madura, Indonesia & US & : Etnik Using \\
\hline B & : bahasa Jawa, Using, Indonesia & $\mathrm{CN}$ & : Etnik Cina \\
\hline $\mathrm{C}$ & : bahasa Madura, Using, Indonesia & $\mathrm{AR}$ & : Etnik Arab \\
\hline $\mathrm{D}$ & $\begin{array}{l}\text { : bahasa Jawa, Dialek Cina, } \\
\text { Indonesia }\end{array}$ & $\mathrm{BU}$ & : Etnik Bugis \\
\hline $\mathrm{E}$ & : bahasa Jawa dan bahasa Indonesia & JA & : Etnik Keturunan Jawa-Asing \\
\hline $\mathrm{F}$ & $\begin{array}{l}\text { : bahasa Madura dan bahasa } \\
\text { Indonesia }\end{array}$ & JB & : Etnik Keturunan Jawa-Bugis \\
\hline G & : bahasa Using dan bahasa Indonesia & $\mathrm{JM}$ & : Etnik Keturunan Jawa-Madura \\
\hline $\mathrm{H}$ & $\begin{array}{l}\text { : bahasa Jawa, Madura, Using, dan } \\
\text { Indonesia }\end{array}$ & JU & : Etnik Keturunan Jawa-Using \\
\hline JW & : Etnik Jawa & MU & : Etnik Keturunan Madura-Using \\
\hline MA & : Etnik Madura & MI & : Etnik Minahasa \\
\hline
\end{tabular}

Di SMP Negeri VII Jember siswa yang bilingual (yang menguasai bahasa daerah etnik lain) berjumlah 58 orang atau 46\% dari 126 responden. Di SMP Negeri I Sukorambi siswa yang bilingual (yang menguasai bahasa daerah etnik lain) berjumlah 36 orang atau 30\% dari 122 responden.

Out put pengajaran dan pembelajaran bahasa daerah kedua pada bilingualisme siswa dapat ditelusuri melalui pemeriksaan Tabel (1) dan (4). Caranya menghubungkan dua variabel, yaitu bahasa daerah yang diajarkan di sekolah dan bahasa ibu (bahasa pertama) siswa, kemudian disinkronisasi dengan kebilingualan siswa. Kedua variabel itu harus berbeda untuk dapat menambah repertoire bahasa siswa. Jadi, pengaruh itu hanya bisa dilihat pada siswa yang bahasa ibunya tidak sama dengan bahasa daerah yang diajarkan di sekolah. Luaran (out put) pengajaran bahasa daerah terhadap kebilingualan siswa dapat dirumuskan: repertoire bahasa ibu + repertoire bahasa daerah yang diajarkan di sekolah. Luaran pengajaran bahasa bahasa daerah di enam SMP Negeri yang diteliti dapat dilihat pada tabel pada kolom yang diarsir.

Tabel (4), jika dicermati, diperoleh penjelasan bahwa proses pengajaran dan pembelajaran bahasa daerah di sekolah-sekolah tersebut hanya menghasilkan kebilingualan pada para siswa yang termasuk dalam golongan etnik minoritas. Dampak proses pengajaran dan pembelajaran itu adalah siswa yang termasuk dalam golongan etnik mayoritas lebih mendalami bahasanya sendiri dan kurang memahami bahasa etnik minoritas. Wajar jika para siswa dari golongan etnik mayoritas banyak yang tidak memiliki kemampuan beralih bahasa ketika berkomunikasi dengan etnik lain (lihat Tabel (6) dan (7)) karena terkendala oleh faktor kemampuan bahasa (lihat Tabel (9)). Pengajaran bahasa daerah di sekolah-sekolah multietnik idealnya menghasilkan kemampuan bilingualisme yang timbal balik. Artinya, yang kecil memahami yang besar dan yang besar memahami yang kecil.

Kebilingualan siswa juga dapat diperoleh melalui jalur informal, di antaranya melalui pendidikan dalam keluarga, pergaulan di kampung atau pergaulan di lingkungan sekolah. Pemerolehan Kebilingualan siswa melalui jalur pendidikan informal dapat dilihat pada Tabel (5) berikut. Jalur pendidikan informal ini justru menyajikan berbagai bahasa yang ada di masyarakat. Sehingga anak dapat belajar bahasa-bahasa itu melalui pergaulannya. 
Tabel 5. Pemerolehan Bahasa Daerah Kedua oleh Siswa di Luar Sekolah

\begin{tabular}{|c|c|c|c|c|c|c|}
\hline \multirow{2}{*}{ Daerah } & \multirow{2}{*}{ Etnik } & \multicolumn{4}{|c|}{ Bahasa daerah } & \multirow{2}{*}{$\begin{array}{c}\text { Jumlah } \\
\text { Responden }\end{array}$} \\
\hline & & A & B & $\mathrm{C}$ & $\mathrm{D}$ & \\
\hline Kapongan & MA & 6 & 6 & 1 & - & 13 \\
\hline \multirow[t]{2}{*}{ Mangaran } & MA & 2 & 4 & 2 & 1 & \multirow{2}{*}{12} \\
\hline & $\mathrm{JM}$ & 1 & 2 & - & - & \\
\hline Rogojampi & JW & 1 & 2 & - & - & 3 \\
\hline \multirow[t]{3}{*}{ Muncar } & JW & 1 & 4 & 2 & 3 & \multirow{3}{*}{14} \\
\hline & $\mathrm{JU}$ & - & - & 1 & 1 & \\
\hline & KB & - & - & - & 2 & \\
\hline \multirow[t]{3}{*}{ Patrang } & JW & 8 & 18 & 2 & 6 & \multirow{3}{*}{45} \\
\hline & US & - & 1 & - & - & \\
\hline & $\mathrm{JM}$ & 1 & 5 & - & 4 & \\
\hline \multirow[t]{3}{*}{ Sukorambi } & JW & 3 & 11 & 4 & 1 & \multirow{2}{*}{20} \\
\hline & $\mathrm{JM}$ & - & 1 & - & - & \\
\hline & & 23 & 54 & 12 & 18 & \\
\hline
\end{tabular}

Keterangan:
A: Dalam ling. Keluarga
D:Campuran di antara A sampai dengan $\mathrm{C}$
B: Pergaulan di kampung
MA: Madura, JW: Jawa, US: Using
C: Pergaulan di ling. Sekolah
JM: Jawa-Madura, JU: Jawa-Using

\subsection{Implikasi kebilingualan Siswa dalam Komunikasi Antaretnik}

Dalam masyarakat multietnik nilai-nilai yang mendasari perilaku berbahasa itu adalah nilai-nilai multikulturalisme. Sebagaimana dikemukakan oleh para pengamat dan pengkaji multikulturalisme, seperti Fay (1996), Jary dan Jary (1991), Watson (2000), May dan Collin (2001), Nieto (2000), Pamungkas (2003), Rahardjo (2005), dan Supriyoko (2005) bahwa multikulturalisme itu merupakan pandangan, sikap, dan perilaku yang berazaz pada keadilan, kesederajatan, solidaritas sosial, tenggang rasa, saling menghargai, dan humanisme. Nilai-nilai itu akan tertuang dalam setiap perilaku berbahasa seseorang. Perilaku berbahasa adalah perilaku komunikatif yang mencakup kelakuan seseorang yang dipengaruhi oleh faktor eksternal (seperti situasi tutur, topik pembicaraan, dan hubungan sosial penutur dengan petutur) saat memilih atau menggunakan salah satu bahasa atau varietas bahasa dalam peristiwa komunikasi; atau saat melakukan tindak bahasa.

Seseorang yang memiliki kemampuan kedwibahasaan (bilingualisme), memiliki potensi untuk sering mengganti bahasa atau ragam bahasa; hal ini tergantung pada keadaan atau keperluan berbahasa itu. Situasi berbahasa yang berbeda-beda (seperti, pemeran serta, lokasi, jalur, tujuan, dan sebagainya) mempengaruhi terjadinya peristiwa alih kode. Umpamanya, sewaktu kita berbahasa A dengan si P datang si Q yang tidak dapat berbahasa A memasuki situasi berbahasa itu. Oleh karena kita ingin menerima $Q$ dalam situasi berbahasa itu, maka kita beralih memakai bahasa B yang dimengerti Q. Kejadian seperti itu kita sebut alih kode. Konsep alih kode ini mencakup juga kejadian di mana kita beralih dari satu ragam fungsiolek (umpamanya ragam santai) ke ragam lain (umpamanya ragam formal), atau dari satu dialek ke dialek yang lain, dan sebagainya (Nababan, 1984).

Berdasarkan kerangka teoritik di atas kita akan melihat sejauh mana faktor kebilingualan dan pandangan multikultur siswa menjadi daya dorong untuk melakukan alih bahasa pada saat mereka berkomunikasi dengan orang lain yang berbeda etnik. 


\section{Implementasi Kebijakan Pembinaan Bahasa Daerah di Kabupaten Jember, Situbondo dan Banyuwangi (Budi Suyanto)}

Tabel 6. Kesanggupan Mengorientasi Diri kepada Mitra Bicara dengan Cara Menggunakan Bahasa Daerah Lawan Bicara

\begin{tabular}{|c|c|c|c|c|}
\hline \multirow[t]{2}{*}{ Daerah } & \multicolumn{3}{|c|}{$\begin{array}{l}\text { Kesanggupan Mengorientasi diri pada P2 yang } \\
\text { Berbeda Etnik ketika Berbicara }\end{array}$} & \multirow[t]{2}{*}{ Responden } \\
\hline & $\mathrm{Ya}$ & Tidak & Tidak Jawab & \\
\hline Mangaran & 22 & 23 & - & 45 \\
\hline Kapongan & 23 & 15 & - & 38 \\
\hline Muncar & 29 & 77 & - & 106 \\
\hline Rogojampi & 56 & 34 & - & 90 \\
\hline Sukorambi & 45 & 28 & - & 73 \\
\hline \multirow[t]{2}{*}{ Patrang } & 40 & 57 & - & 97 \\
\hline & 215 & 234 & & 449 \\
\hline
\end{tabular}

Menurut Poedjosoedarmo (1979) peristiwa alih kode, si pembicara bukan sekedar mengambil alih kata atau sejumlah kata dari kode lain, tetapi si pembicara paling sedikit mengambil satu klausa dari kode lain. Jadi, di sini peristiwa masuknya unsur asing tidak terbatas dalam leksikon saja, tetapi sudah menyangkut unit sintaksis yang lebih besar. Peristiwa alih kode karena alasan-alasan atau maksud-maksud tertentu.

Esensi alih kode dalam peristiwa percakapan antaretnik dapat dijelaskan dengan dua pendekatan, yaitu sosiolinguistik dan multikulturalisme. Alih kode menurut pendekatan yang pertama adalah peralihan pemakaian dari suatu bahasa atau dialek ke bahasa atau dialek ke dialek lainnya. Alih kode sepenuhnya terjadi karena perubahan sosiokultural, situasi berbicara, topik, status sosial, penutur, dan sebagainya (Ohoiwutun, 1997). Sedangkan alih kode dilihat dari perspektif multikulturalisme adalah peralihan bahasa ke bahasa lain sematamata untuk menunjukkan sikap akomodatif dan menghargai atas keterlibatan etnik lain dalam sebuah pembicaraan. Alih kode yang terjadi karena perubahan topik atau karena menyitir ucapan seseorang dalam bahasa lain tidak termasuk dalam alih kode multikulturalisme. Sedangkan, konsep multikulturalisme itu sendiri dapat diartikan sebagai faham yang menghargai keberagaman. Faham yang berazaskan pada keadilan, kesetaraan (egaliter), toleransi, dan saling menghargai.

Kesadaran seseorang untuk beralih alih bahasa (kode) merupakan refleksi dari sikap multikulturnya. Rendahnya kesadaran siswa untuk beralih bahasa sebagaimana tampak pada Tabel 7 disebabkan oleh keterbatasan kemampuan bilingualismenya.

Tabel 7. Kesadaran Penggunaan Bahasa Lawan Bicara yang Berbeda Etnik dan Bahasa

\begin{tabular}{lccc}
\hline \multirow{2}{*}{ Daerah } & \multicolumn{3}{c}{ Kesadaran Beralih Bahasa dalam Komunikasi antaretnik } \\
\cline { 2 - 4 } & Ya & Tidak & Tidak Jawab \\
\hline Mangaran & 42 & 75 & 1 \\
Kapongan & 20 & 74 & 7 \\
Muncar & 41 & 76 & 7 \\
Rogojampi & 40 & 72 & 3 \\
Sukorambi & 50 & 64 & 8 \\
Patrang & 32 & 89 & 5 \\
\hline
\end{tabular}


Siswa yang memiliki kemampuan bilingualisme yang memadai memiliki sikap yang lebih asosiatif dan akomodatif terhadap lawan bicara yang berbeda etnik dengannya. Sikap asosiatif ini berupa keinginan seseorang untuk menyatu atau mendekat dengan orang lain; sedangkan sikap akomodatif adalah sikap menerima segala sesuatu dari pihak lain. Sikap asosiatif dan akomodatif dalam perilaku bahasa salah satunya diwujudkan dengan pemakaian bahasa lawan bicara. Besaran sikap asosiatif yang dimiliki oleh para siswa dapat dilihat pada Tabel 8 berikut ini.

Tabel 8. Alasan Mengorientasi diri P1 ke dalam Bahasa P2

\begin{tabular}{lccc}
\hline \multirow{2}{*}{ Daerah } & \multicolumn{2}{c}{ Alasan mengorientasi diri } & \multirow{2}{*}{ Responden } \\
\cline { 2 - 3 } & Agar lebih akrab & Tidak tahu & 22 \\
Mangaran & 21 & 1 & 23 \\
Kapongan & 22 & 1 & 29 \\
Muncar & 21 & 8 & 53 \\
Rogojampi & 49 & 4 & 44 \\
Sukorambi & 40 & 4 & 39 \\
Patrang & 38 & 1 & 210 \\
\hline
\end{tabular}

Tabel 9. Alasan Tidak Mengorientasi diri terhadap Lawan Bicara Beda Etnik

\begin{tabular}{lcccc}
\hline \multirow{2}{*}{ Daerah } & \multicolumn{2}{c}{ Alasan tidak mengorientasi diri P2 } & \multirow{2}{*}{ Responden } \\
\cline { 2 - 4 } & $\begin{array}{c}\text { Tidak Menguasai } \\
\text { Bahasanya }\end{array}$ & $\begin{array}{c}\text { Tidak Suka } \\
\text { Bahasanya }\end{array}$ & Tidak Tahu & \\
\hline Mangaran & 17 & - & 6 & 23 \\
Kapongan & 7 & 1 & 5 & 13 \\
Muncar & 68 & - & 7 & 75 \\
Rogojampi & 29 & 2 & 2 & 33 \\
Sukorambi & 23 & 2 & 4 & 29 \\
Patrang & 45 & 1 & 8 & 54 \\
\hline & 189 & 6 & 32 & 227 \\
\hline
\end{tabular}

Tabel 8 dapat dipahami bahwa secara teoretis ada dua prinsip yang mengatur perilaku berbahasa seseorang, yaitu prinsip pemilihan bahasa dan prinsip retorik. Kedua prinsip ini mengorientasi perilaku bahasa penutur terhadap petutur agar tercipta hubungan sosial yang baik dan terhindar dari konflik. Prinsip-prinsip ini bersumber pada nilai-nilai multikulturalisme, seperti keadilan, toleransi, solidaritas (sifat satu rasa), egalitarianisme (merasa sederajat), dan tenggang rasa (dapat menghargai perasaan orang atau pihak lain). Nilai-nilai tersebut sangat cair dan berpadu dalam membentuk sistem sosial.

Nilai multikulturalisme teraktualisasi pada perilaku seseorang ketika ia terlibat dalam sebuah percakapan. Ia harus membuat kesepakatan sebanyak-banyaknya kepada orang yang diajak bicara (petutur), memilih salah satu kode yang memberi kemudahan pemahaman dan menguntungkan pada petutur. Kesepakatan ini cenderung mengarah kepada penggunaan 


\section{Implementasi Kebijakan Pembinaan Bahasa Daerah di Kabupaten Jember, Situbondo dan Banyuwangi (Budi Suyanto)}

bahasa yang dikuasai atau dimengerti oleh petutur. Adil membagi peran berbicara atau memberi kesempatan kepada partisipan lain untuk berbicara, menghargai pembicaraan atau cara atau gaya berbicara seseorang, dan menanggapi pembicaraan seseorang secara positif, menggunakan kode yang tidak bertentangan dengan nilai-nilai egalitarianisme, memberi respon positif terhadap setiap perubahan komponen tutur.

Siswa yang tidak melakukan alih bahasa pada saat berkomunikasi dengan siswa lain yang berbeda etnik (Tabel (7)) tidak dapat dikatakan bahwa mereka tidak memiliki sikap akomodatif sama sekali, tapi ada alasan yang kuat mereka tidak melakukan itu. Alasan itu adalah keterbatasan kemampuan menuturkan bahasa daerah lawan bicaranya. Pada Tabel (9) besaran kuantifikasi pada pilihan "tidak menguasai bahasanya" memperkuat pernyataan ini.

\subsubsection{Wawasan Multikulturalisme Para Siswa}

Perilaku bahasa anak pada dasarnya dilandasi oleh norma sosial, pengetahuan, dan perasaannya. Simpati kepada orang lain adalah perbuatan yang sangat sopan. Sikap inilah yang memungkinkan untuk merealisasi tindakan hormat, tenggang rasa, dan adil terhadap orang lain. Simpati juga memungkinkan seseorang untuk menjalin hubungan silaturohmi dan kerja sama dengan orang lain. Tabel 10, 11, dan 12 merupakan refleksi dari gambaran umum sikap manusiawi yang ada di dalam pikiran dan perasaan para siswa. Pikiran dan perasaan itu merupakan potensi yang sangat positif untuk membentuk kohesivitas sosial.

Tabel 10, 11, dan 12 merupakan hasil penjaringan dari para siswa yang menyatakan memiliki jaringan sosial dengan etnik lain, sehingga validitas informasi yang disampaikan dapat dipercaya.

Tabel 10. Rasa Simpati terhadap Etnik Lain

\begin{tabular}{lcccccc}
\hline & \multicolumn{5}{c}{ Perasaan terhadap Etnik lain } & \\
\cline { 2 - 6 } \multicolumn{1}{c}{ Daerah } & Suka & & Biasa Saja & Tidak & Tidak & Responden \\
& & & & Suka & Jawab & \\
\hline Mangaran & 26 & 91 & - & 1 & 118 \\
Kapongan & 17 & 83 & 1 & - & 101 \\
Muncar & 41 & 77 & 1 & 5 & 124 \\
Rogojampi & 43 & 71 & - & 1 & 115 \\
Sukorambi & 32 & 88 & 2 & - & 122 \\
Patrang & 41 & 83 & - & 2 & 126 \\
\hline & 200 & 493 & 4 & 9 & 706 \\
\hline
\end{tabular}


Tabel 11. Kesediaan Menjalin Interaksi Sosial dengan Etnik Lain

\begin{tabular}{|c|c|c|c|c|}
\hline \multirow{2}{*}{ Daerah } & \multicolumn{3}{|c|}{ Jaringan Sosial dengan Etnik Lain } & \multirow{2}{*}{ Responden } \\
\hline & Punya & Tidak Punya & Tidak Jawab & \\
\hline Mangaran & 45 & 72 & 1 & 118 \\
\hline Kapongan & 38 & 62 & 1 & 101 \\
\hline Muncar & 106 & 16 & 2 & 124 \\
\hline Rogojampi & 90 & 24 & 1 & 115 \\
\hline Sukorambi & 73 & 47 & 2 & 122 \\
\hline \multirow[t]{2}{*}{ Patrang } & 97 & 26 & 3 & 126 \\
\hline & 449 & 247 & 10 & 706 \\
\hline
\end{tabular}

Tabel 12. Kesanggupan Menjalin Kerjasama dengan Etnik Lain

\begin{tabular}{lcccc}
\hline & \multicolumn{3}{c}{ Keinginan menjalin kerja sama dengan etnik } & \\
Daerah & Ya & Tidak & Tidak & Respon \\
\cline { 2 - 4 } & & 42 & 2 & \\
\hline Mangaran & 74 & 49 & 2 & 118 \\
Kapongan & 50 & 8 & 2 & 101 \\
Muncar & 114 & 15 & 2 & 124 \\
Rogojampi & 98 & 52 & 1 & 115 \\
Sukorambi & 69 & 22 & 6 & 122 \\
Patrang & 98 & 188 & 15 & 126 \\
\hline
\end{tabular}

Potensi yang positif itu harus disaranai atau didukung oleh kemampuan bilingualisme yang bermuatan bahasa-bahasa yang ada di lingkungan masyarakatnya. Tanpa kemampuan bilingualisme ini, potensi positif siswa tidak akan dapat direalisasi dengan baik. Potensi ini seharusnya dikembangkan dalam dunia pendidikan kita melalui proses pendidikan dan pengajaran yang tepat.

Pengajaran bahasa daerah yang bermuatan multilingual sangat dimungkinkan karena di samping sikap akomodatif dan keinginan untuk menjalin hubungan silaturohmi dan kerja sama juga didukung oleh adanya minat para siswa untuk mempelajari kesenian dan tradisi etnik lain (lihat Tabel 13 dan bahasa etnik lain Tabel 14). 


\section{Implementasi Kebijakan Pembinaan Bahasa Daerah di Kabupaten Jember, Situbondo dan Banyuwangi (Budi Suyanto)}

Tabel 13. Minat Siswa Mempelajari Kesenian dan Tradisi Etnik Lain

\begin{tabular}{lcccr}
\hline & \multicolumn{4}{c}{$\begin{array}{c}\text { Minat Mempelajari Kesenian dan Tradisi } \\
\text { Etnik Lain }\end{array}$} \\
\cline { 2 - 4 } Daerah & Ya & Tidak & $\begin{array}{c}\text { Tidak } \\
\text { Jawab }\end{array}$ \\
\hline Mangaran & 92 & 26 & - & 118 \\
Kapongan & 74 & 25 & 2 & 101 \\
Muncar & 118 & 8 & 5 & 124 \\
Rogojampi & 102 & 11 & 2 & 115 \\
Sukorambi & 96 & 24 & 2 & 122 \\
Patrang & 121 & 4 & 1 & 126 \\
\hline & 603 & 94 & 12 & 709 \\
\hline
\end{tabular}

Tabel 14. Minat Siswa Mempelajari Bahasa Etnik Lain di Sekolah

\begin{tabular}{|c|c|c|c|c|}
\hline \multirow{2}{*}{ Daerah } & \multicolumn{3}{|c|}{ Minat mempelajari bahasa daerah etnik lain } & \multirow{2}{*}{ Responden } \\
\hline & $\mathrm{Ya}$ & Tidak & Tidak Jawab & \\
\hline Mangaran & 108 & 10 & - & 118 \\
\hline Kapongan & 84 & 14 & 3 & 101 \\
\hline Muncar & 112 & 9 & 3 & 124 \\
\hline Rogojampi & 99 & 14 & 2 & 115 \\
\hline Sukorambi & 104 & 16 & 2 & 122 \\
\hline \multirow[t]{2}{*}{ Patrang } & 121 & 4 & 1 & 126 \\
\hline & 628 & 67 & 11 & 706 \\
\hline
\end{tabular}

\subsubsection{Perlakuan Diskriminatif yang Dialami oleh Para Siswa}

Unsur lain yang masih terkait dengan kultur adalah masalah diskriminasi. Diskriminasi adalah perlakuan yang tidak adil terhadap orang atau kelompok lain. Diskriminasi mempunyai hubungan erat dengan relasi antara kelompok yang dominan dengan yang minoritas karena perlakuan yang tidak adil, biasanya, sering berasal dari kelompok dominan terhadap kelompok minoritas." Perlakuan tidak adil atau tindakan diskriminatif bisa terjadi dalam berbagai bidang kehidupan seperti ekonomi, politik, sosial, budaya, pendidikan, bahasa, dan lain-lain. Perbedaan-perbedaan kultural seperti perbedaan agama, suku, ras, klas sosial, gender, umur dan bahasa dapat dijadikan objek dan alasan untuk melakukan diskriminasi oleh kelompok dorminan terhadap kelompok minoritas (Yakin, 2005).

Bentuk diskriminasi ada dua macam, yaitu diskriminasi institusional dan diskriminasi individual. Diskriminasi individual yaitu bersikap tidak adil kepada orang lain hanya karena alasan pribadi belaka. Diskriminasi ini biasanya dilakukan oleh mdividu-individu. Seorang guru tidak memperdulikan salah seorang muridnya, la tidak peduli apakah si murid itu paham atau tidak terhadap apa yang dijelaskannya. Si guru berbuat demikian hanya karena dia mempunyai perasaan tidak suka secara pribadi terhadap si murid (Yakin, 2005).

Diskriminasi institusional yaitu perlakuan tidak adil terhadap seseorang atau sekelompok orang yang berasal dari golongan tertentu, terutama dari kelompok mayoritas, di 
dalam institusi-institusi atau organisasi-organisasi pemerintahan maupun swasta. Diskriminasi institusional ini biasanya dilakukan oleh sekelompok orang dari golongan tertentu yang dominan dan sangat kuat dalam sebuah institusi, sehingga terlihat, seakan-akan, institusi itu yang melakukan diskriminasi. Di dalam sebuah kantor pemerintahan yang mayoritas pegawainya berasal dari suku "N' maka jabatan-jabatan strategis, terutama jabatan kepala kantor, akan selalu diduduki oleh orang-orang yang berasal dari suku yang sama, apabila ada orang lain yang berasal dari suku lainnya, maka is akan mendapat kesulitan untuk menduduki jabatan-jabatan strategis di kantor tersebut. Diskriminasi institusional juga dapat terjadi pada wilayah-wilayah sosial yang lebih luas seperti desa, kecamatan, kabupaten, propinsi, dan bahkan dapat terjadi dalam sebuah institusi negara.

Para siswa yang hidup di tengah-tengah masyarakat multietnik dan multikultur menghadapi berbagai kenyataan yang ada di dalam masyarakat. Mereka mengalami dan melihat kejadian-kejadian yang terjadi di dalam masyarakatnya terkait dengan masalah diskriminasi ini dengan intensitas yang berbeda-beda. Tabel berikut merupakan hasil penjaringan terhadap pengalaman para siswa dalam kehidupannya sehari-hari, baik di dalam keluarga, di kampung, maupun di sekolah.

Tabel 15. Pengalaman Siswa Mendapat Ejekan dari Pihak Lain karena Keetnikannya

\begin{tabular}{lcccc}
\hline \multirow{2}{*}{ Daerah } & \multicolumn{3}{c}{$\begin{array}{c}\text { Pengalaman dipandang rendah karena } \\
\text { keetnikan }\end{array}$} & Responden \\
\cline { 2 - 4 } & Pernah & Tidak pernah & Tidak Jawab & \\
\hline Mangaran & 42 & 71 & 5 & 118 \\
Kapongan & 24 & 77 & - & 101 \\
Muncar & 28 & 94 & 2 & 124 \\
Rogojampi & 35 & 78 & 2 & 115 \\
Sukorambi & 45 & 77 & - & 122 \\
Patrang & 55 & 68 & 3 & 126 \\
\hline & 229 & 465 & 12 & 706 \\
\hline
\end{tabular}

Tabel 16. Pengalaman Melihat Orang Lain Bersikap Deskriminatif di Lingkungan Sekolah karena Berbicara dengan Bahasa Daerahnya

\begin{tabular}{lcccc}
\hline \multirow{2}{*}{ Daerah } & \multicolumn{3}{c}{$\begin{array}{c}\text { Pengalaman melihat kejadian orang bersikap } \\
\text { deskriminatif terhadap orang lain karena bahasa yang } \\
\text { dituturkannya }\end{array}$} & \\
\cline { 2 - 4 } Responden \\
\cline { 2 - 4 } Mangaran & Pernah & Tidak pernah & Tidak Jawab & \\
Kapongan & 47 & 71 & - & 118 \\
Muncar & 30 & 70 & 1 & 101 \\
Rogojampi & 52 & 70 & 2 & 124 \\
Sukorambi & 36 & 76 & 3 & 115 \\
Patrang & 66 & 56 & - & 122 \\
\hline & 35 & 434 & - & 126 \\
\hline
\end{tabular}

Tabel 15 dan 16 ditafsirkan bahwa diskriminasi masih menyelimuti kehidupan sosial para siswa. Pilihan pada jawaban pada kolom "pernah" dengan nilai kuantifikasi 229 (Tabel 


\section{Implementasi Kebijakan Pembinaan Bahasa Daerah di Kabupaten Jember, Situbondo dan Banyuwangi (Budi Suyanto)}

15) dan 266 (Tabel 16) membuktikan bahwa di lingkungan masyarakat para siswa masih memiliki intensitas kejadian yang cukup tinggi. Menurut pengakuan sebagian siswa bahwa dirinya pernah mendapat perlakuan dan pernah memperlakukan orang lain secara deskriminatif. Pengakuan para siswa tersebut menunjuk bahwa di kalangan siswa masih ada sikap deskriminatif. Artinya, wawasan multikulturalisme siswa masih kurang baik. Kebilingualan siswa masih belum berfungsi optimal sebagai sarana pemahaman budaya secara lintas etnik. Kondisi ini harus diubah melalui penerapan pendidikan multikulturalisme sejak dini.

\section{Penutup}

Pengajaran bahasa daerah di sekolah sangat berpengaruh pada kemampuan bilingualisme anak didik. Namun tidak semua siswa memperoleh kemampuan yang sama. Pengaruh yang cukup signifikan diperoleh oleh siswa yang bahasa ibunya tidak diajarkan di sekolah. Para siswa ini diuntungkan karena mendapat kompetensi bahasa etnik lain. Artinya mereka memiliki kemampuan bilingual yang lebih baik. Para siswa dari golongan etnik minoritas Using atau Madura di Jember, etnik Jawa atau Using di Situbondo, atau etnik Madura di Banyuwangi dari golongan minoritas yang justru memperoleh repertoire linguistik yang lebih luas jika dibandingkan dengan siswa dari golongan mayoritas.

Siswa dari golongan etnik minoritas dengan kemampuan bilingualnya secara signifikan memiliki kesanggupan untuk membuat jaringan sosial yang lebih luas dibandingkan dengan siswa dari golongan etnik mayoritas. Repertoire linguistik yang dimiliki memungkinkan mereka menjalin interaksi sosial dengan orang lain yang berbeda etnik.

Siswa golongan etnik minoritas lebih akomodatif terhadap siswa lain yang berbeda etnik. Sikap akomodatif tersebut diwujudkan dalam perilaku bahasa yang berupa alih bahasa. Siswa golongan etnik mayoritas cenderung menggunakan bahasa Indonesia saat menjalin interaksi sosial dengan etnik minoritas. Fakta ini dapat ditafsirkan bahwa kesanggupan mereka menjalin hubungan secara lintas bahasa lebih rendah apabila dibandingkan dengan kesanggupan siswa etnik minoritas. Perilaku bahasa dalam masyarakat multietnik semacam ini menggambarkan sikap multikulturalisme para siswa.

\section{Daftar Pustaka}

Fay, Brian. 1996. Contemporary Philosophy of Social Science: A Multicultural Approach. Oxford: Blackwell.

Jary, David dan Julia Jary. 1991. "Multiculturalism". Hal. 319. Dictionary of Sociology. New York: Harper.

May, Larry, dan Shari Collin. 2001. Etika Terapan I dan II: Sebuah Pendekatan Multikultural. Penerjemah Sinta Caroline, dkk. Yogyakarta: Gad.jah Mada University Press. 
Mulyana, Deddy. 2001. Metodologi Penelitian Kualitatif: Paradigms Baru 11mu Komunikasi dan 11mu Social Lainnya. Bandung: Remaja Rosdakarya.

Nababan, PWJ. 1984. Sosiolinguistik suatu Pengantar. Gramedia: Jakarta.

Nieto, Sonia. 2000. Affirming Diversity: The Sociopolitical Cotext of Multicultural Education. New York: Longman.

Ohiowutun, Paul. 1997. Sosiolinguistik.: Memahami Bahasa dalam Konteks Masyarakat dan Kebudayaan. Jakarta: Visipro.

Pamungkas, Arie Setyaningrum. 2003. "The Australian Multiculturalism and the Global Chalengges". Thesis (unpublished). University of Sydney:

Australia.

Rahardjo, Turnomo. 2005. Menghargai Perbedaan Kultural: Mindfulness dalam Komunikasi Antaretnis. Pustaka Pelajar: Yogyakarta.

Sudaryanto. 1990. Menguak Fungsi Hakiki Bahasa. Duta Wacana University Press: Yogyakarta.

Suparlan. Parsudi. 2002. "Kesetaraan Warga dan Hak Budaya Komuniti dalam Masyarakat Majemuk Indonesia". Jurnal Antropologi Indonesia. No. 6. hal. 1-12.

Supriyoko, Ki. 2005. Pendidikan Multikultural dan Revitalisasi Hukum Adat: dalam Perspektif Sejarah. Jakarta: Departemen Kebudayaan dan Pariwisata.

Watson, C.W. 2000. Multiculturalism. Buckingham-Philadelpia: Open University Press.

Yakin, Ainul. 2005. Pendidikan Multikultural: Cross-Cultural Understanding untuk Demokrasi dan Keadilan. Yogyakarta: Nuansa Aksara. 